\title{
Mycological quality of pecan nuts from Brazil: absence of aflatoxigenic fungi and aflatoxins
}

\author{
Marcelo Valle Garcia ${ }^{1}$ (D) Vivian Machado Moraes ${ }^{1}$ Angélica Olivier Bernardi $^{1}$ (iD \\ Maurício Schneider Oliveira ${ }^{2}$ Carlos Augusto Mallmann² Jardel Boscardin ${ }^{3}$ (D) \\ Marina Venturini Copetti ${ }^{1 *}$ (iD
}

${ }^{1}$ Departamento de Tecnologia e Ciência dos Alimentos, Universidade Federal de Santa Maria (UFSM), 97105-900, Santa Maria, RS, Brasil. E-mail: mvc@smail.ufsm.br. *Corresponding author.

${ }^{2}$ Laboratório de Análises Micotoxicológicas (LAMIC), Universidade Federal de Santa Maria (UFSM), Santa Maria, RS, Brasil.

${ }^{3}$ Instituto de Ciências Agrárias, Universidade Federal de Uberlândia (UFU), Campus Monte Carmelo, Monte Carmelo, MG, Brasil.

ABSTRACT: In recent years, Brazil has encouraged the cultivation of pecans to meet both demands of domestic and international market of nuts. New genetic varieties of pecans have been selected in recent years, but available scientific information on the occurrence of fungi and aflatoxins in the international literature is out of date. Therefore, the present study aimed to quantify and identify fungal microbiota and the presence of aflatoxins in pecan nuts cultivated in southern Brazil. Fifty-two pecan nut lots (Barton variety) were obtained from producers from 19 cities of Rio Grande do Sul State and analyzed by direct plating in Agar Dichloran Glycerol 18\% (DG18) and Aspergillus Flavus and Parasiticus Agar (AFPA), following incubation at $25{ }^{\circ} \mathrm{C}$ for 7 days. Aflatoxins analyses were carried out using HPLC coupled with a mass spectrometer. Results revealed at least 10 different genera of fungi. Aspergillus, Penicillium, Fusarium, and Cladosporium were predominant. Xerophilic species of Aspergillus (A. wentii, A. ruber, A. pseudoglaucus, and A. chevalieri) were commonly reported in the samples. No potential aflatoxin-producing species was isolated and no aflatoxins were detected ( $L O Q=1 \mu \mathrm{g} / \mathrm{kg}$ and $L O D=0.1 \mu \mathrm{g} / \mathrm{kg}$ for AFB1 and AFB2, and $0.3 \mu \mathrm{g} / \mathrm{kg}$ for AFG1 and AFG2) in the evaluated samples. The absence of this carcinogenic group of mycotoxins is highly positive and could boost the investments in the sector, as well as stimulate the commercialization and consumption of this variety of nut.

Key words: Aspergillus, Penicillium, Mycotoxin, Rio Grande do Sul, Carya illinoinensis.

Qualidade micológica de nozes pecan do Brasil: ausência de fungos aflatoxigênicos e aflatoxinas

RESUMO: Nos últimos anos, o Brasil tem incentivado o cultivo de pecãs para atender a demanda do mercado nacional e internacional de nozes. Novas variedades genéticas de pecãs foram selecionadas nos últimos anos, mas informações cientificas disponíveis sobre a ocorrência de fungos e aflatoxinas na literatura internacional estão desatualizadas. Portanto, o presente estudo objetivou quantificar e identificar a microbiota fúngica e a presença de aflatoxinas em nozes cultivadas no sul do Brasil. Cinquenta e dois lotes de nozes (variedade Barton) foram obtidos de produtores de 19 municipios do Estado do Rio Grande do Sul e analisados por meio de Ágar Dicloran Glicerol 18\% (DG18) e Aspergillus Flavus e Parasiticus Agar (AFPA), após incubação em $25{ }^{\circ} \mathrm{C}$ durante 7 dias. Análises de aflatoxinas foram realizadas usando HPLC acoplado a um espectrômetro de massa. Os resultados revelaram pelo menos 10 gêneros diferentes de fungos. Aspergillus, Penicillium, Fusarium e Cladosporium foram predominantes. Espécies xerofilicas de Aspergillus (A. wentii, A. ruber, A. pseudoglaucus e A. chevalieri) foram comumente encontradas nas amostras. Nenhuma espécie potencial produtora de aflatoxinas foi isolada e nenhuma aflatoxina foi detectada ( $L O Q=1 \mu \mathrm{g} / \mathrm{kg}$ e $L O D=0,1 \mu \mathrm{g} / \mathrm{kg}$ para AFB1 e AFB2; e 0,3 $\mathrm{gg} / \mathrm{kg}$ para AFG1 e AFG2) nas amostras avaliadas. A ausência desse grupo carcinogênico de micotoxinas é altamente positiva e pode impulsionar os investimentos no setor, além de estimular a comercialização e o consumo dessa variedade de nozes.

Palavras-chave: Aspergillus, Penicillium, Micotoxina, Rio Grande do Sul, Carya illinoinensis.

\section{INTRODUCTION}

The pecan nut [Carya illinoinensis (Wangenh.) K. Koch] is a native plant of North America that naturally occurs in the United States of America and southern Mexico. These countries are responsible for about $90 \%$ of the production in the world, with South Africa, Australia, China,
Peru, Chile, Israel, and Brazil gradually entering this market (PECAN REPORT, 2018). Currently, commercial cultivation of this plant is practiced throughout the 3 southern states (Rio Grande do Sul, Paraná, and São Paulo). Rio Grande do Sul has been the biggest producer since 2013, which according to agricultural data from Brazilian perennial crops (IBGE, 2019), represents $47.8 \%$ of all 2017 nut 
production in Brazil. Moreover, pecan production has been expanding in this state and climatologic studies by ROVANI \& WOLMANN (2018) have shown favorable conditions for its cultivation, with very low risk in $41.8 \%$ of its territory.

Regarding their nutritional characteristics, pecans present considerable amounts of mono $(40.8 \%)$ and polyunsaturated fatty acids $(21.6 \%)$, as well as linoleic acid (20.6\%) and minerals (potassium, magnesium, and calcium) (ROS, 2010). According to McKAY et al. (2018), a pecan-rich diet can decrease the risk of cardiometabolic diseases (cardiovascular diseases and type 2 diabetes).

During the different stages of cultivation and processing, pecan nuts are exposed to contamination by a wide variety of microorganisms, especially fungi, which can multiply in this substrate, changing nut quality, producing unpleasant flavors, and even possibly synthesizing mycotoxins, especially aflatoxins (TERABE et al., 2008; PITT \& HOCKING, 2009). Among the major fungal species reported in pecan nuts are Penicillium spp. (ORTIZ \& CAMARGO, 2005) and Aspergillus spp. (HUANG \& HANLIN, 1975; BEUCHAT, 1975), such as Aspergillus flavus and Aspergillus parasiticus, which are important aflatoxinproducing fungi (PITT \& HOCKING, 2009).

Intake of foods containing mycotoxins can seriously affect animal and human health (PITT, 2000), in which aflatoxins stand out for their toxicity. Aflatoxin B1 is the most carcinogenic natural compound known and classified in group 1 by the International Agency for Research on Cancer (IARC) (IARC, 1993). For nuts, Brazilian legislation establishes an acceptable maximum limit of $10 \mu \mathrm{g} / \mathrm{kg}$ for total aflatoxins (BRASIL, 2011).

Studies on mycology of pecans are scarce and most of the available research is outdated and from the ' $70 \mathrm{~s}$, not reflecting the pecan cultivars introduced in recent crops. Additionally, data on fungal species colonizing pecan nuts cultivated in Brazil is limited, and studies evaluating aflatoxins in this product have yet to be reported. Therefore, the objective of this research was to quantify and identify fungal microbiota associated with pecan nuts cultivated and processed in Brazil, in addition to investigating the presence of aflatoxins in the samples.

\section{MATERIALS AND METHODS}

Fifty-two pecan nut (C. illinoinensis, Barton variety) samples (at least $250 \mathrm{~g}$ ) corresponding to 52 different lots from different producers from 4 regions of Rio Grande do Sul State (RS), Brazil, were analyzed
(Figure 1). Samples were collected during the raw material reception stage, from a processing company located in Cachoeira do Sul (RS), which is the city that most processes pecan nuts in Brazil.

Samples had their water activity (aw) determined in duplicate directly on a water activity meter (Aqualab Series $4 \mathrm{TE}, \mathrm{USA}$ ) at $25{ }^{\circ} \mathrm{C} \pm 1$. For mycological analyses, the samples were shelled and the nuts disinfected for 2 minutes in $0.4 \%$ sodium hypochlorite solution. Twenty half-pieces of nuts were arranged in 4 Petri dishes containing Dichloran Glycerol 18\% Agar (DG18) and also in Aspergillus Flavus and Parasiticus Agar (AFPA). Plates were incubated at $25{ }^{\circ} \mathrm{C} \pm 1$ for 7 days. Results were expressed as a percentage (\%) of fungal infection (PITT \& HOCKING, 2009).

The frequency of occurrence (FO\%) of a fungal species was determined according to the following equation:

$$
\mathrm{FO} \%=\left(\frac{\mathrm{NSF}}{\mathrm{TNS}}\right) \times 100
$$

Where: NFS: number of samples with a certain fungus; TNS: the total number of samples.

The fungi were isolated and grown in Czapek Yeast Extract Agar (CYA) and Malt Extract Agar (MEA) for identification. The genus Penicillium was identified according to PITT (2000) and FRISVAD \& SAMSON (2004). Identification of Aspergillus sp. and other fungi were performed according to PITT \& HOCKING (2009), except for Aspergillus section Aspergillus (formerly Eurotium), which followed CHEN et al. (2017).

After mycological analyses, pecan nuts were sent to the Laboratory of Mycotoxicological Analyses (LAMIC) for aflatoxins analyses. The analyses were performed by the method proposed by SULYOK et al. (2006) adapted to laboratory conditions. Briefly, $20 \mathrm{~mL}$ of acetonitrile: water solution (84:16, v/v) was added to a $5 \mathrm{~g}$ sample and conducted to a shaker (Lucadema, São Paulo, Brazil) for 1 hour and 30 minutes at $70 \mathrm{rpm}$.

Then, the extract was properly diluted (1:10) and $10 \mu \mathrm{L}$ of the diluted extract injected in a 1200 Series Infinity HPLC (Agilent, Palo Alto, USA) coupled with a 5500 QTRAP mass spectrometer (Applied Biosystems, Foster City, USA) equipped with an Electrospray ionization (ESI) source in positive mode. Chromatographic separation was performed at $30^{\circ} \mathrm{C}$ with an Eclipse XDB-C8 column (4.6 x $150 \mathrm{~mm}, 5 \mu \mathrm{m}$ particle diameter) (Agilent, Palo Alto, USA) with the mobile phase gradient composed of solutions of methanol: water: ammonium acetate (95:4:1, v/v/v) (solution A) and water: ammonium acetate $(99: 1, \mathrm{v} / \mathrm{v})$ (solution $\mathrm{B})$. 


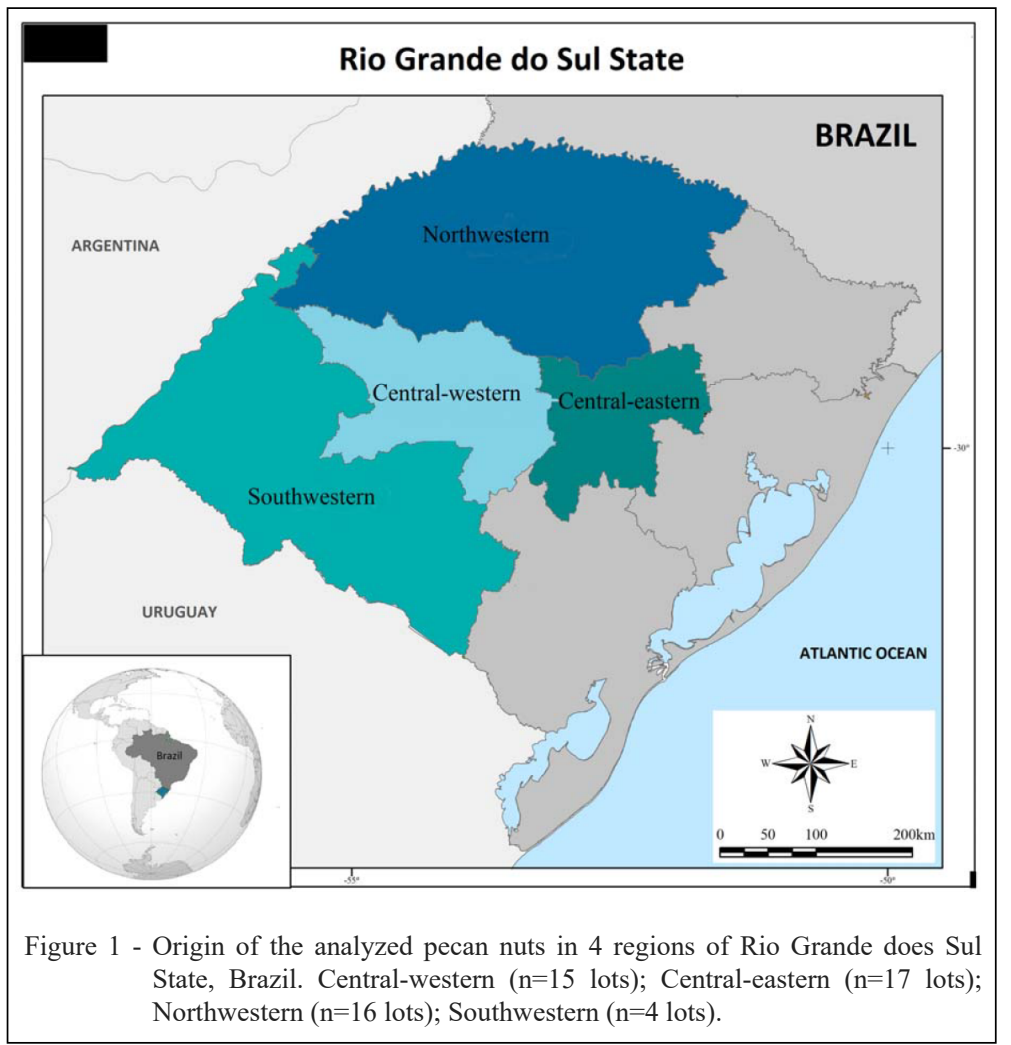

To ensure the reliability of the obtained results, the matrix effect, accuracy and precision of the analytical method were evaluated. In addition, peanut certified reference material was analyzed, since, for matrix pecan nuts, there was no certified reference material available. Also, a pecan nut sample free of aflatoxins contamination was fortified with a known concentration $(10 \mu \mathrm{g} / \mathrm{kg})$ and analyzed together with the samples from this study.

Recovery tests using contamination-free samples were performed to evaluate the accuracy and precision of the method. Seven samples were fortified at three concentration levels $(2.5,5.0$ and $10 \mu \mathrm{g} / \mathrm{kg})$ of each aflatoxin. After analysis, the mean, standard deviation, and coefficient of variation for each concentration were calculated. The mean recovery $(\%)$ and coefficient of variation values reported were 90.9/1.7; $90.7 / 0.7 ; 89.9 / 1.7 ; 91.7 / 1.7$; respectively for $\mathrm{AFB}_{1}, \mathrm{AFB}_{2}, \mathrm{AFG}_{1}$ and $\mathrm{AFG}_{2}$.

For data analyses, variance analysis (ANOVA) was performed. The range of fungal contamination and water activity values were separated using the Tukey test $(\mathrm{P}<0.05)$. Statistical analyses were performed using version 5.6 of SISVAR Software (FERREIRA, 2014). Also, we performed hierarchical clustering to generate clusters and heatmaps. Heatmaps are a discovery-based visualization method that allows for simultaneous view of the hierarchical clustering in both the rows (fungi) and the columns (regions of RS). This is accomplished by providing a color code to each frequency of occurrence (FO). For example, if a fungus has a high value for its FO, this is assigned a color intensity of red whereas if other has a low value for FO, a color intensity of yellow is assigned. To perform these analyses were used the GGplot2 package in R (R DEVELOPMENT TEAM, 2016).

\section{RESULTS AND DISCUSSION}

Ten genera and 19 species of different fungi were identified in the analyzed pecan nut samples (Table 1). Significant differences $(p<0.05)$ were reported between the level of fungal contamination and water activity (aw) according to the sample region of origin.

Aspergillus was the most common genus identified among the samples. It was the most prevalent in 3 out of the 4 regions sampled. The most frequent Aspergillus species were xerophiles $[A$.

Ciência Rural, v.49, n.6, 2019. 
Table 1 - Occurrence of fungi associated with pecan nuts from different regions of origin in the Rio Grande do Sul State, Brazil.

\begin{tabular}{|c|c|c|c|c|c|c|}
\hline & $\begin{array}{c}\text { Central-western } \\
(n=15)\end{array}$ & Cent & $\begin{array}{l}\text { tral-eastern } \\
(n=17)\end{array}$ & $\begin{array}{l}\text { North western } \\
\quad(n=16)\end{array}$ & $\begin{array}{l}\text { South western } \\
\qquad(n=4)\end{array}$ & $\begin{array}{l}\text { Total of state } \\
\quad(n=52)\end{array}$ \\
\hline$\% \bar{x}$ Infection (range) & $73.5^{\mathrm{ab}} \quad(30-100)$ & $88.0^{\mathrm{b}}$ & $(60-100)$ & $72.5^{\mathrm{ab}} \quad(40-100)$ & $50.0^{\mathrm{a}} \quad(35-55)$ & $72.4 \quad(30-100)$ \\
\hline $\bar{x}$ Aw (range) & $0.746^{\mathrm{ab}}(0.64-0.90)$ & 0.788 & $(0.75-0.80)$ & $0.737^{\mathrm{ab}}(0.71-0.77)$ & $0.721^{\mathrm{a}}(0.68-0.75)$ & $0.753(0.64-0.90)$ \\
\hline Filamentous fungi & FO $(\%)$ & & $\mathrm{FO}(\%)$ & FO $(\%)$ & $\mathrm{FO}(\%)$ & $\mathrm{FO}(\%)$ \\
\hline Alternaria sp. & ND & & ND & ND & 50.0 & 3.84 \\
\hline Aspergillus sp. & 86.7 & & 100 & 87.5 & 100 & 93.5 \\
\hline A. candidus & 6.66 & & ND & ND & ND & 1.92 \\
\hline A. nidulans & ND & & 5.88 & ND & ND & 1.92 \\
\hline A. niger & ND & & ND & 12.5 & ND & 3.84 \\
\hline A. penicillioides & ND & & 5.88 & ND & ND & 1.92 \\
\hline A. versicolor & ND & & ND & ND & 25.0 & 1.92 \\
\hline A. wentii & 46.7 & & 29.41 & 25 & 50.0 & 34.6 \\
\hline A. chevalieri & 20.0 & & 17.65 & 31.2 & 25.0 & 25.0 \\
\hline A. pseudoglaucus & 33.3 & & 41.18 & ND & 25.0 & 26.9 \\
\hline A. ruber & 46.7 & & 23.53 & 25 & 75.0 & 34.6 \\
\hline Cladosporium sp. & 33.3 & & 29.41 & 31.2 & 25.0 & 30.8 \\
\hline Colletotrichum sp. & 6.66 & & ND & ND & ND & 1.92 \\
\hline Fusarium sp. & 33.3 & & 23.5 & 31.2 & 75.0 & 32.7 \\
\hline Nigrospora sp. & ND & & 23.5 & 18.8 & ND & 13.5 \\
\hline Penicillium sp. & 80 & & 88.2 & 93.8 & 75.0 & 84.2 \\
\hline P. brevicompactum & 20 & & 11.76 & ND & ND & 9.61 \\
\hline P. citrinum & 20 & & 11.76 & 12.5 & 50 & 17.3 \\
\hline P. commune & ND & & 11.76 & ND & ND & 3.84 \\
\hline P. corylophilum & ND & & ND & 6.25 & ND & 1.92 \\
\hline P. crustosum & ND & & 5.88 & 6.25 & ND & 3.85 \\
\hline P. fellutanum & ND & & 5.88 & ND & ND & 1.92 \\
\hline P. lividum & 6.66 & & ND & ND & ND & 1.92 \\
\hline P. olsonii & 13.3 & & 11.8 & 12.5 & 50 & 15.4 \\
\hline$P$. paxilli & 20 & & 17.6 & 12.5 & 50 & 19.2 \\
\hline P. solitum & 6.66 & & ND & 6.25 & ND & 3.85 \\
\hline Trichoderma sp. & 6.66 & & ND & ND & ND & 1.92 \\
\hline Verticillium sp. & ND & & 5.88 & ND & ND & 1.92 \\
\hline Rhizopus sp. & 13.3 & & ND & ND & 25.0 & 7.69 \\
\hline \multicolumn{7}{|l|}{ Not identified } \\
\hline Dematiaceous fungi & 53.3 & & 29.4 & 37.5 & 75.0 & 42.3 \\
\hline Mycelia sterilia & 46.7 & & 23.5 & 37.5 & 50.0 & 36.5 \\
\hline
\end{tabular}

*Different letters on the same line indicate significant differences by Tukey's test $(\mathrm{P}<0.05)$.

FO: Frequency of occurrence (number of samples showing that fungus/total number of samples analyzed x 100); ND: Not detected. $\overline{\mathrm{X}}=$ Average.

wentii, isolated from about $1 / 3$ of all samples, $A$. ruber (formerly E. rubrum) (34.6\%), A. pseudoglaucus (formerly E. repens) $(26.9 \%)$ and A. chevalieri (formerly $E$. chevalieri) (25\%)], which can grow in minimal aw of 0.70 to 0.79 (ANDREWS \& PITT, 1987). According to HUANG \& HANLIN (1975), $A$. ruber and $A$. pseudoglaucus increased tremendously during storage and were commonly reported in market pecans.

The higher similarity in the fungal diversity was reported between samples from the Northwestern and Central-eastern of the state, and from the Southwestern were the most divergent (Figure 2). No toxigenic Aspergilli were isolated in both culture 
media employed. The most common aflatoxin producers are A. flavus and A. parasiticus, which have already been reported in pecans (LILLARD et al., 1970; HUANG \& HANLIN, 1975; KOEHLER et al., 1975, TERABE et al., 2008).

Penicillium sp., was the most prevalent in one region and the second most prevalent in the other three regions sampled. Among the Penicillia, P. paxilii (19.2\%), P. citrinum (17.3\%), and P. olsonii (15.4\%) were, in general, the dominant species in the samples. In a study conducted by HUANG \& HANLIN (1975), Penicillium sp. was the most common genus recovered from fresh harvest pecans (part of mycobiota) and the second in predominance, after Aspergillus sp., which is similar to our observations. In that study, $P$. citrinum was the most common Penicillium sp. isolated at storage (HUANG \& HANLIN, 1975). Despite its widespread occurrence worldwide, this genus is specially adapted to regions with milder temperatures, such as Rio Grande do Sul, located at latitude $30^{\circ}$.

Fusarium was the third most prevalent genus and isolated from about $1 / 4$ to $3 / 4$ of the samples analyzed in all regions. This genus is considered a field fungus with considerable importance regarding mycotoxin production (PITT \& HOCKING, 2009), and is more common in freshly harvested pecans, decreasing during storage (HUANG \& HANLIN, 1975).

Fungi of the genus Cladosporium were isolated from $30 \%$ of our analyzed samples. This genus is a well-known pathogen of pecan nuts and causes a disease known as "scab". The species Cladosporium cladosporioides, Cladosporium pseudocladosporioides, and Cladosporium subuliforme are responsible for this disease in southern Brazil (WALKER et al., 2016).

Alternaria sp. was only isolated in samples from the southwestern region in half of the samples collected. Species of Alternaria have been associated with darkly discolored pecan kernels, usually discarded during processing (SCHROEDER \& COLE, 1976).

TERABE et al. (2008) reported important deteriorating and mycotoxigenic microorganisms in pecan nuts produced in Paraná, such as Alternaria sp., A. ochraceus, A. flavus, A. niger, Cladosporium sp., Colletotrichum sp., Fusarium sp., Penicillium sp.,

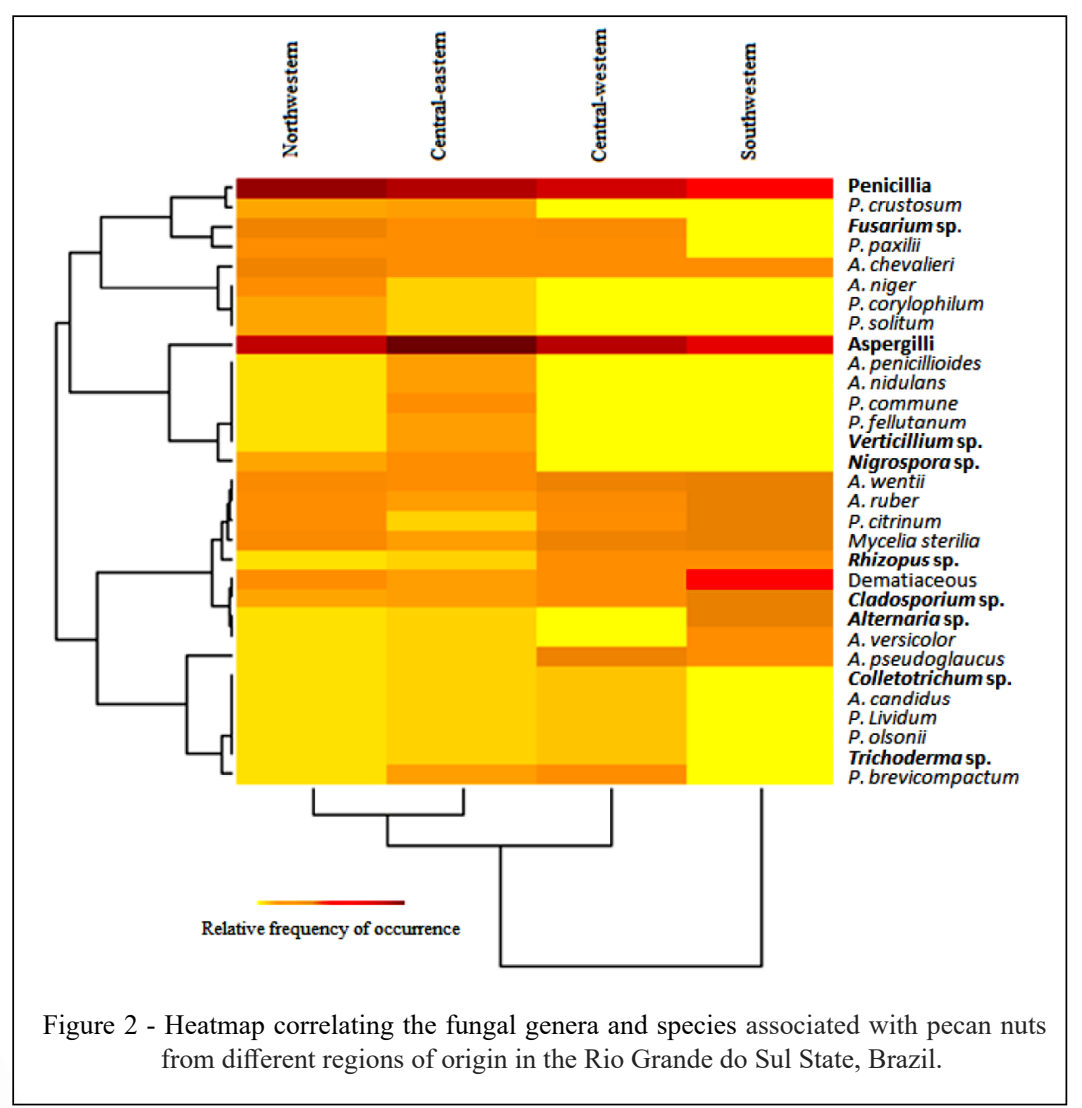

Ciência Rural, v.49, n.6, 2019. 
and Rhizopus sp. Some species, except for Aspergilli with the potential of producing mycotoxins, are consistent with the results of this research. Even with the presence of toxigenic species in Paraná samples, no mycotoxin analyses were performed. Therefore, this study was the first to investigate the presence of aflatoxins in Brazilian pecan nuts.

The researchers (TERABE et al., 2008) studied three growing pecan cultivars (Frotcher, Burkett, and Moneymaker), reporting variation in the infection by toxigenic Aspergilli (both $A$. flavus, A. niger, and A. ochraceus) during storage, being the Frotcher cultivar the most susceptible to contamination. Moreover, VÁZQUEZ-BARRIOS et al. (2001) showed that $A$. parasiticus develops faster than A. flavus in pecan nuts and that susceptibility to infection by Aspergilli varies significantly within pecan genotypes, suggesting the possibility of selecting pecan cultivars with a high level of resistance to infection by aflatoxigenic species aiming mycotoxin control. Differences among genotypes may explain the absence of aflatoxigenic fungi in our study, which only evaluated Barton variety.

Conversely, our study was the first to evaluate the presence of aflatoxins in pecan nuts produced in Brazil. These mycotoxins were not detected in any of the 52 pecan nut lots analyzed. In order to ensure the reliability of the results obtained in the analyses, the quantification limit (LOQ) $(1 \mu \mathrm{g} / \mathrm{kg})$ and detection limit (LOD) $(0.1 \mu \mathrm{g} / \mathrm{kg}$ for aflatoxins B1 and $\mathrm{B} 2$; and $0.3 \mu \mathrm{g} / \mathrm{kg}$ for aflatoxins $\mathrm{G} 1$ and $\mathrm{G} 2$ ) were calculated through the signal-to-noise ratio (LOQ $=10 / 1, L O D=3 / 1)$, respectively. The matrix effect was evaluated by comparing the analytical curve prepared in a solvent without the addition of matrix and analytical curve prepared with the addition of a matrix. After application of the Test F (Snedecor), it was considered the absence of matrix effect, because of $\mathrm{F}_{\text {calculated }}<\mathrm{F}_{\text {tabulated }}$. Certified reference material identified by the number FAPAS 04256 showed satisfactory results since the values found are within the range of Z-score -2 and +2 .

In agreement with our data, the absence of aflatoxins in pecans has also been reported in studies from the United Kingdom $(n=2)$ (CAC, 2004) and Portugal ( $n=2)$ (CUNHA et al., 2018). On the other hand, contamination by these mycotoxins has already been evidenced in the United States of America (ESCHER et al., 1974) and Mexican pecans (ADAYA-GONZÁLEZ et al., 2015).

When compared to other nuts, pecans appear to present lower amounts of accumulated aflatoxins (CAC, 2004). According to ADAYA-
GONZÁLEZ et al. (2015), values ranging from 0.23 to $1.30 \mathrm{ng} / \mathrm{g}$ for total aflatoxins were found in 16 pecan nuts collected in Mexico, while walnuts and cashew nuts showed values ranging from 0.05 to $12.10 \mathrm{ng} / \mathrm{g}$. Also, in the European Commission Rapid Alert System for Food and Feed (RASFF) in 2016, aflatoxins were reported in general nuts and nut products and were highlighted between the top 10 notifications. Most of these notifications were for pistachio nuts, groundnuts, and hazelnuts. Pecan nuts were not seen on this report. Thus, consumption of pecan nuts can be a safer alternative among other nuts regarding aflatoxin exposition.

In the present study, despite some samples presenting water activity levels in the range of 0.90 (Table 1 ), the mean value observed was 0.75 . If pecan nuts are properly stored and these values maintained, the possibility of additional production during storage is low. JOHNSSON et al. (2008), for example, showed that aflatoxin production in nuts is favored at a relative humidity of $97 \%$. PITT \& HOCKING (2009) pointed out that aflatoxigenic species, such as A. flavus and A. parasiticus, require a minimum of 0.82 and 0.86 , respectively, for aflatoxin production.

\section{CONCLUSION}

Ten genera of fungi were identified when studying fungal microbiota in early storage of pecan nuts harvested in Southern Brazil. Despite similarities in the fungi isolated, the level of contamination varied according to the pecan region of origin. Xerophilic Aspergilli (A. wentii, A. ruber and A. chevalieri) were the most common species identified. These species are potential spoilers of low activity foods, producing off-flavors in spite of having limited importance as toxin producers. Fortunately, no potentially aflatoxigenic species were isolated and no aflatoxins were detected in the pecan nuts analyzed here. The absence or, at least, not a common occurrence of this highly carcinogenic group of mycotoxins in pecan nuts cultivated in Brazil is highly positive since aflatoxins are compounds of concern in public health and influence the nut market. Thus, consumption of pecan nuts can be a safer alternative among other nuts regarding consumer exposure to aflatoxins.

\section{DECLARATION OF CONFLICT OF INTERESTS}

The authors declare no conflict of interest. The founding sponsors had no role in the design of the study; in the collection, analyses, or interpretation of data; in the writing of the manuscript, and in the decision to publish the results. 


\section{ACKNOWLEDGMENTS}

This study was financed in part by the Coordenação de Aperfeiçoamento de Pessoal de Nível Superior - Brasil (CAPES) - Finance Code 001. Also, we like to thanks to CNPq (Conselho Nacional de Desenvolvimento Científico e Tecnológico, Brazil) for the research grant to MVC (Process 309691/2015-0). Also, we would like to thank Edson Ortiz from Divinut industry of pecans for providing most of the samples used in this study.

\section{AUTHORS' CONTRIBUTIONS}

MVG and MVC conceived and designed experiments. MVG, VMM, and AOB performed the experiments. MSO and CAM carried out the mycotoxins analyses. JB performed statistical analyses of experimental data. MVG and MVC prepared the draft of the manuscript. All authors critically revised the manuscript and approved of the final version.

\section{REFERENCES}

ANDREWS, S. \& PITT. J. I. Further studies on the water relations of xerophilic fungi, including some halophiles. Journal of General Microbiology, v.133, n.233-238, 1987. Available from: <https://www. microbiologyresearch.org/docserver/fulltext/micro/133/2/mic-133-2233.pdf? expires $=1555953463 \& \mathrm{id}=\mathrm{id} \&$ accname $=$ guest $\&$ checksum $=3 \mathrm{E}$ 049011F1A6AEDACD2DD01DB6D164F1>. Accessed: Jan. 05, 2019.

BEUCHAT, L. R. Incidence of molds on pecan nuts at different points during harvesting. Applied Microbiology, [s.1.], v.29, n.6, p.852-854, 1975. Available from: <https://www.ncbi.nlm.nih.gov/ pmc/articles/PMC187092/>. Accessed: Jan. 24, 2019.

BRASIL. Agência nacional de vigilância sanitária - ANVISA Resolução RDC $n^{\circ}$. 7. Dispõe sobre limites máximos tolerados (LMT) para micotoxinas em alimentos. Diário Oficial [da] União, Brasília, DF, Seção 1, p.72, 2011. Available from: <http://portal. anvisa.gov.br/documents/10181/2968262/RDC_07_2011_COMP.pdf/ afe3f054-bc99-4e27-85c4-780b92e2b966>. Accessed: Jan. 05, 2019.

CAC-Codex Alimentarius Commission. Discussion paper on aflatoxins in tree nuts (other than almonds, hazelnuts, and pistachios), including information submitted on aflatoxins contamination and methods of analysis for the determination of aflatoxins in tree nuts. 2004. Available from: <http://www.fao. org/tempref/codex/Meetings/CCFAC/CCFAC36/fa36_22e.pdf>. Accessed: Jan. 23, 2019.

CHEN, A. J., et al. Polyphasic taxonomy of Aspergillus section Aspergillus (formerly Eurotium), and its occurrence in indoor environments and food. Studies in Mycology, v.88, p.37-135, 2017. Available from: <https://doi.org/10.1016/j.simyco.2017.07.001>. Accessed: Mar. 19, 2019. doi: 10.1016/j.simyco.2017.07.001.

CUNHA, S. C. et al. Multiple mycotoxin analysis in nut products: Occurrence and risk characterization. Food and Chemical Toxicology, [s.1.], v.114, p.260-269, 2018. Available from: $<$ https://doi.org/10.1016/j.fct.2018.02.039>. Accessed: Jan. 23, 2019. doi: 10.1016/j.fct.2018.02.039.

ESCHER, F. E. et al. A study on aflatoxin and mold contaminations in improved variety pecans. Journal of Food Science, [s.1.], v.39, n.6, p.1127-1129, 1974. Available from: <https://doi. org/10.1111/j.1365-2621.1974.tb07333.x>. Accessed: Jan. 23, 2019. doi: 10.1111/j.1365-2621.1974.tb07333.x.
FERREIRA, D. F. Sisvar: a Guide for its Bootstrap procedures in multiple comparisons. Ciência e Agrotecnologia, [s. 1.], v. 38, n. 2, p. 109-112, 2014. Available from: <http://dx.doi.org/10.1590/ S1413-70542014000200001>. Accessed: Jan. 23, 2019. doi: $10.1590 / \mathrm{S} 1413-70542014000200001$.

FRISVAD, J. C., SAMSON, R. A. Polyphasic taxonomy of Penicillium subgenus Penicillium. A guide to identification of food and air-borne terverticillate Penicillia and their mycotoxins. Studies in Mycology, v.49, p.1-173, 2004.

HUANG, L. H. \& HANLIN, R. T. Fungi occurring in freshly harvested and in-market pecans. Mycologia, [s. 1.], v.67, n.4, p.689-700, 1975. Available: <https://www.ncbi.nlm.nih.gov/ pubmed/1177964>. Accessed: Jan. 24, 2019.

IARC - International Agency for Research on Cancer. Some naturally occurring substances: food items and constituents, heterocyclic aromatic amines and mycotoxins. Monographs on the evaluation of carcinogenic risk to humans. v.56, p.489-452, 1993. Available from: <https://doi.org/10.1002/ food.19940380335>. Accessed: Jan. 06, 2019. doi: 10.1002/ food. 19940380335 .

IBGE - Instituto Brasileiro de Geografia e Estatística. Produção agrícola em lavouras perenes: noz. 2019. Available from: $<$ https://cidades.ibge.gov.br/brasil/rs/pesquisa/15/11863?tipo=ran king\&indicador=12011\&ano=2017>. Accessed: Jan. 242019.

JOHNSSON, P. et al. Growth of aflatoxigenic moulds and aflatoxin formation in Brazil nuts. World Mycotoxin Journal, [s.1.], v.1, n.2, p.127-137, 2008. Available from: <https://doi.org/10.3920/ WMJ2008.1033>. Accessed: Jan. 24, 2019. doi: 10.3920/ WMJ2008.1033.

KOEHLER, P. E. et al. Production of aflatoxins B1 and G1 by Aspergillus flavus and Aspergillus parasiticus isolated from market pecans. Applied Microbiology, [s.1.], v.30, n.4, p.581-583, 1975. Available from: <https://www.ncbi.nlm.nih.gov/pmc/articles/ PMC187233/>. Accessed: Jan. 06, 2019.

LILLARD, H. S. et al. Aflatoxigenic isolates of Aspergillus flavus from pecans. Applied Microbiology, [s.1.], v.19, n.1, p.128-130, 1970. Available from: <https://www.ncbi.nlm.nih.gov/pmc/ articles/PMC376623/>. Accessed: Jan. 24, 2019.

MCKAY, D. et al. A pecan-rich diet improves cardiometabolic risk factors in overweight and obese adults: a randomized controlled trial. Nutrients, [s.1.], v.10, n.3, p.339, 2018. Available from: $<$ https://doi.org/10.3390/nu10030339>. Accessed: Jan. 24, 2019. doi: $10.3390 /$ nu10030339.

ORTIZ, E. R. N. \& CAMARGO, L. E. A. Doenças da nogueira pecan (Carya illinoinensis). In: Kimati, H. et al. (Org.). Manual de fitopatologia. 4. ed. São Paulo: Agronômica Ceres, 2, 501-506, 2005.

PECAN REPORT. 2018. Available from: <http://www.pecanreport. com>. Accessed: Jan. 242019.

PITT, J.I. A laboratory guide to common Penicillium species. Common wealth Scientific and Industrial Research Organization, Sydney, 197p, 2000.

PITT, J.I. \& HOCKING, A.D. Fungi and food spoilage, 3 ed. Springer, New York, 2009.

Ciência Rural, v.49, n.6, 2019. 
R Development Core Team R: A language and environment for statistical computing R Foundation for Statistical Computing Viena, Austria, 2016. Available from: <http://cran-r.c3sl.ufpr.br $>$. Accessed: Jan. 25, 2019.

RASFF - Rapid Alert System for Food and Feed. Annual Report, 2016. Available from: <https:/ec.europa.eu/food/ sites/food/files/safety/docs/rasff_annual_report_2016.pdf>. Accessed: Jan. 24, 2019.

ROS, E. Health Benefits of Nut Consumption. Nutrients, [s.1.], v.2, n.7, p.652-682, 2010. Available from: <https:// doi.org/10.3390/nu2070652>. Accessed: Jan. 24, 2019. doi: $10.3390 /$ nu2070652.

ROVANI, F. F. M. \& WOLLMANN, C. A. Análise sazonal e anual dos requisitos climáticos do cultivo da nogueira pecã (Carya illinoinensis) no Rio Grande do Sul. GEOUSP: Espaço e Tempo (Online), [s.1.], v.22, n.1, p.191-209, 2018. Available from: $<$ https://doi.org/10.11606/issn.2179-0892.geousp.2018.122043>. Accessed: Jan. 24, 2019. doi: 10.11606/issn.2179-0892. geousp.2018.122043.

SAMSON, R. A. \& FRISVAD, J. C. Penicillium subgenus Penicillium: new taxonomic schemes, mycotoxins, and other extrolites. Studies in Mycology, 49, 1-260, 2004.

SCHROEDER, H. W. \& COLE, R. J. Natural occurrence of alternariols in discolored pecans. Journal of Agricultural and
Food Chemistry, [s.1.], v.25, n.1, p.204-206, 1977. Available from: <https://doi.org/10.1021/jf60209a032>. Accessed: Jan. 24, 2019.

SULYOK, M. et al. Development and validation of a liquid chromatography/tandem mass spectrometric method for the determination of 39 mycotoxins in wheat and maize. Rapid Communications in Mass Spectrometry, [s.1.], v.20, n.18, p.2649-2659, 2006. Available from: <https://doi.org/10.1002/ rcm.2640>. Accessed: Jan. 24, 2019. doi: 10.1002/rcm.2640.

TERABE, N. I. et al. Microrganismos associados a frutos de diferentes cultivares de noz Pecan. Ciência e Agrotecnologia, [s.1.], v.32, n.2, p.659-662, 2008. Avaliable from: <http://dx.doi. org/10.1590/S1413-70542008000200049>. Accessed: Jan. 24, 2019. doi: 10.1590/S1413-70542008000200049.

VÁZQUEZ-BARRIOS, $M$. et al. Development of toxigenic Aspergillus flavus and A. parasiticus on kernels of native pecan [Carya illinoinensis (Wangenh) K. Koch] genotypes under different water activities. Scientia Horticulturae, [s.1.], v.89, n.2, p.155-169, 2001. Available from: $<$ https://doi.org/10.1016/S03044238(00)00225-9>. Accessed: Jan. 24, 2019. doi: 10.1016/S03044238(00)00225-9.

WALKER, C. et al. First report of species in the Cladosporium cladosporioides complex causing pecan leaf spot in Brazil. Journal of Plant Pathology, [s.1.], n.2, 2016. Available from: $<$ https://doi.org/10.4454/JPP.V98I2.012>. Accessed: Jan. 24, 2019. doi: 10.4454/JPP.V98I2.012. 